\title{
A Study on Enlightenment to Most Developing Countries from Xi Jinping's Thought in the Rule by Law
}

\author{
Zhong-wei DUAN ${ }^{1,{ }^{*}}$ and Yan-jun DAI ${ }^{2}$ \\ ${ }^{1}$ School of Marxism, Dalian University of Technology, Dalian, China \\ ${ }^{2}$ School of Marxism, Dalian University of Technology, Dalian, China \\ *duanzw@dlut.edu.cn
}

Keywords: The rule by the law, The nomocracy ideology of Xi Jinping, Globalization of the law.

\begin{abstract}
The formation and perfection of Xi Jinping's thought in the all-round rule by law is under the background of the impact of globalization on the rule of law and the realistic need of building up a well-off society in an all-round way. Xi Jinping's thought has made great achievements in the theory breakthrough in the interpretation of the aim and implementation way of the rule by the law, the dialectical relationship between the Party, the reform and the rule by the law, which has great significance for the construction of the rule of law in developing countries.
\end{abstract}

\section{Introduction}

China, as the largest developing country, has made great achievements in the development of economic and the rule by law. Especially, when Xi Jinping had been coming to power in 2012, he put forward the thought in the all-round rule by law based on the national conditions and the requirements of the times, which has pushed further forward to the construction of the rule by law and has great significance for the construction of the rule of law in developing countries.

\section{On the Background of the Formation of Xi Jinping's Thought in the Rule by Law}

\section{The Impact of the Globalization of the Rule of Law}

In the tide of globalization, the mode of the rule by law in Western countries based on separation of powers is sweeping the whole world and has been making great affection on the vast developing countries. However, after all, the customs and culture are different between countries. The universality of the Western mode is facing the challenge for its classification and logic in globalization. Since the Reform and Open to the Outside World, under the influence of globalization, the construction of China in the rule by law is increasingly different from western countries, which has gradually formed nomocracy theory of socialism with Chinese characteristics. Xi Jinping's thought in the all-round rule by law is its latest developments.

\section{The Realistic Need of Building up a Well-off Society in an All-round Way.}

Building up a well-off society in an all-round way is the Communist Party's objective of a struggle founded in the new stage of new century, which has made clear and higher requirements for the construction of economic, political, cultural, social, ecological and other aspects of our country. In order to meet this requirement, $\mathrm{Xi}$ Jinping put forward the important idea of governing the country according to law, which was understanded and grasped in the strategic plans to complete the building of 
a moderately prosperous society in all respects, and to comprehensively deepen reform, advance law-based governance, and enforce strict Party conduct. He expounds profoundly the mutual relationship between comprehensively law-based governance and the building of a moderately prosperous society in all respects, between comprehensively law-based governance and comprehensively deepen reform, between comprehensively law-based governance and comprehensively strict Party conduct in order to make full use of the security function of law-based governance and provide scientific theoretical guidance to achieve the goal of building a moderately prosperous society in an all-round way.

\section{On the Basic Content of Xi Jinping's Thought in the Rule by Law}

\section{The Goal of the Construction in the Rule by Law}

The new goal of building a country ruled by law in China was first presented by General Secretary Xi Jinping on behalf of the Central Committee of the Communist Party of China, which was officially recognized by the third Plenary Session of 18th Party Central Committee. In January 2013, the television and telephone conference about national political and legal work was held. Before this conference, Xi Jinping made important instructions for the political and legal work under new circumstances. The instructions made particular emphasis on that law enforcement authorities around the country should promote the projects of Security China, building a country ruled by law in China, and training a team with high comprehensive quality in order to conform to the people's new expectations of public safety, justice, and the protection of rights and interests [1]. The goal of building a country ruled by law in China has attracted a wide spread attention since put forward.

\section{The Implementation Paths of the Construction in the Rule by Law}

In order to realize the goal of the construction in the rule by law, Xi Jinping as General Secretary on behalf of the Central Committee of the Communist Party of China has put forward eight implementation paths: the first is to push the rule by law, the law-based governance and the law-based administration forward in collaboration; the second is to push the construction of country, government and society in the rule by forward in collaboration; the third is to promote scientific legislation and improve the Socialist Legal System with Chinese Characteristics with the constitution as the commander; the fourth is to administrate strictly according to law and speed up the building of a law-based government; the fifth is to persist in judicial justice and try to make everyone feel fairness and justice in every judicial case; the sixth is to enhance the nationwide legal concept and make law respecting and abiding be common pursue and self-conscious action among people throughout the country; the seventh is to train a team with high comprehensive quality; the eighth is to seize leaders who are vital few among all practitioners.

\section{Dialectical Relationship between the Party and the Rule by Law}

"The relationship between the party and law is a fundamental problem. If this problem were handled well, the Party, country and law-based governance would all be up in the ascendant; if this problem were not properly handled, the Party, country and law-based governance would all go downhill" [2]. On the relationship between the party and the rule by law, Xi Jinping pointed out that "the leadership of the Party is the most essential feature of socialism with Chinese characteristics, and it is the most fundamental guarantee of socialist legal system" [3], "the Party and law, the Party's 
leadership and the rule by law are highly unified. Undoubtedly, we are absolutely carrying out the rule and governance by the constitution of the people's Republic of China, which is the basis for us making all these judgments [4]." Xi Jinping makes it clear that the Chinese Communist Party takes up the central and leading position and plays the role of political guarantee. Xi Jinping also makes it clear that the dialectical unity relation and internal consistency between the Party and the rule by law, from the perspective of the inner coherence between the Party's position and the people's will, which has solved deeply and comprehensively the fundamental problem of the relationship between the party and law.

\section{Dialectical Relationship between Reform and the Rule by Law}

The relationship between reform and the rule by law is not only vital for the legitimacy and effectiveness of the reform, but also vital for the continuous improvement and sustainable development of the rule by law. About this important theoretical problem, Xi Jinping pointed out that "every important reform must have legislative authority according to due procedures and the law can be the first to be amended if needed based on the principle of construction before destruction and orderly development" [5], "In order to ensure that the reform is taken into the legal tract, we should attach great importance to the use of legal frameworks and legal methods during the whole process of the reform, to play the leading and promoting rule of the rule by law, to strengthen the coordination of the relevant legislation[6]." The important exposition of General Secretary Xi Jinping is a relocation of the relationship between reform and the rule by law, is a great major adjustment to the past decision patterns that reform is given priority to the rule by law, which makes it clear that the dialectical unity relation and internal consistency between reform and the rule by law in mutual promotion and protection.

\section{On Enlightenment to Most Developing Countries from Xi Jinping's Thought in the Rule by Law}

\section{The Construction of the Rule by Law Must Comply with the Requirements of the Times and Highlight Its Own Characteristics}

At present, the vast number of developing countries is at a time, whose construction of the rule by law is facing the full range of influence from the experience of modernization in western countries. If completely accepted, it would not be acclimatized, while if completely refused, it would not keep pace with the times. Drawing lessons from Xi Jinping's thought, most developing countries should have every confidence in their path, theories and system with an open mind facing challenges, promote comprehensive innovation on the basis of criticism without superstition and rejection, and take a road in line with their own national conditions with unique characteristics.

\section{The Construction of the Rule by Law Must Have a Clear Goal and Comprehensive Implementation Paths}

At present, the goal of most developing countries in the construction is not clear; the path is not comprehensive and so on. Drawing lessons from Xi Jinping's thought, most developing countries should establish a clear and specific goal based upon the present and future from both of the macroscopic and microcosmic angle in order to clarify the direction and highlight the focus. After the establishment of the goal, comprehensive implementation paths should be structured in participants, operations 
and range involved, which include country, government and society, include legislation, law execution, and judicature.

\section{The Construction of the Rule by Law Must Adhere to the Principle of Dialectical Unity and Ensure Mutual Security}

The construction of the rule by law is a systematic project. Each step forward and the relationship between the relevant parties must be properly handled. Otherwise it would be extremely prone to setbacks, and even suffered serious setback. Drawing lessons from Xi Jinping's thought, developing countries should properly deal with the relationship between law-based governance and reform, law-based governance and the ruling party and construct the dialectical unity relationship in mutual promotion and protection.

\section{References}

[1]Peng Bo, law enforcement authorities around the country should promote the projects of Security China, building a country ruled by law in China, and training a team with high comprehensive quality in order to conform to the people's new expectations of public safety, justice, and the protection of rights and interests, People's daily, 2013-1-8(1). (In Chinese)

[2] Xi Jinping, Speech on comprehensively promoting the rule by law at the provincial and ministerial level leading cadres to study and implement the spirit of the third Plenary Session of 18th Party Central Committee, in: Literature Research Office of the Central Committee of the Communist Party of China (Eds.), Selected discussions about the all-round rule by law from Xi Jinping, Literature of the Central Committee Press, Beijing, 2015, pp.33. (In Chinese)

[3] Xi Jinping, Explanation of the decision of the Central Committee of the Communist Party of China on major issues concerning comprehensively promoting the rule by law, in: Document Compilation of the forth Plenary Session of 18th Party Central Committee, People's Publishing House, Beijing, 2014, pp.78-79. (In Chinese)

[4] Xi Jinping, Speech on comprehensively promoting the rule by law at the provincial and ministerial level leading cadres to study and implement the spirit of the third Plenary Session of 18th Party Central Committee, in: Literature Research Office of the Central Committee of the Communist Party of China (Eds.), Selected discussions about the all-round rule by law from Xi Jinping, Literature of the Central Committee Press, Beijing, 2015, pp.36. (In Chinese)

[5] Xi Jinping, Speech on comprehensively promoting the rule by law at the provincial and ministerial level leading cadres to study and implement the spirit of the third Plenary Session of 18th Party Central Committee, in: Literature Research Office of the Central Committee of the Communist Party of China (Eds.), Selected discussions about the all-round rule by law from Xi Jinping, Literature of the Central Committee Press, Beijing, 2015, pp.45-46. (In Chinese)

[6] Xi Jinping, Speech on comprehensively promoting the rule by law at the provincial and ministerial level leading cadres to study and implement the spirit of the third Plenary Session of 18th Party Central Committee, in: Literature Research Office of the Central Committee of the Communist Party of China (Eds.), Selected 
discussions about the all-round rule by law from Xi Jinping, Literature of the Central Committee Press, Beijing, 2015, pp.46. (In Chinese) 